\title{
BODY IMAGE, PERILAKU MAKAN DAN STATUS GIZI REMAJA
}

\author{
Body Image, Eating Behavior and Nutritional Status in Adolescents
}

\section{Ni Luh Agustini Purnama}

\section{Program Studi Profesi Ners STIKES Katolik St. Vincentius a Paulo Surabaya}

\section{Riwayat artikel}

Diajukan: 20 Agustus 2021

Diterima: 31 Agustus 2021

\section{Penulis Korespondensi:}

- $\quad$ Ni Luh Agustini Purnama

- Program Studi Profesi Ners STIKES Katolik St. Vincentius a Paulo Surabaya

e-mail:

niluh.purnama20@gmail.co $\underline{\mathrm{m}}$

\section{Kata Kunci:}

Body Image, Perilaku Makan, Status Gizi, Remaja

\begin{abstract}
Abstrak
Pendahuluan : Remaja sangat memerlukan zat gizi yang seimbang untuk peningkatan pertumbuhan fisik dan perkembangan yang sangat pesat. Di Indonesia sendiri permasalahan gizi pada remaja yang kompleks yaitu obesitas, gizi kurang serta kekurangan zat gizi mikro seperti anemia. Status gizi remaja dipengaruhi oleh berbagai faktor seperti perilaku makan dan body image. Tujuan: Penelitian ini bertujuan mengindetifikasi hubungan perilaku makan, body image dengan status gizi remaja. Metode: Desain penelitian menggunakan cross sectional. Responden sebanyak 62 remaja di SMAK Karitas 3 Surabaya yang memenuhi kriteria inklusi yang diambil dengan teknik simple random sampling. Perilaku makan dinilai dengan menggunkan Eating Behavior Patterns Questionnaire. Body image dinilai dengan kuesioner dan status gizi remaja berdasarakan indek masa tubuh. Hasil: Penelitian menunjukkan sebanyak 56,5\% remaja memiliki gambaran body image yang positif, 93,5\% remaja denga prilaku makan yang sehat dan sebesar 35,5\% status gizi berdasarkan indeks masa tubuh berada pada kategori normal. Uji korelasi Spearman menunjukkan ada hubungan yang signifikan antara body image dengan status gizi remaja, dengan korelasi negatif ( $\mathrm{p}$ $=0,0001, r=-0,447)$. Tidak ada hubungan antara perilaku makan dengan status gizi remaja ( $\mathrm{p}=0,711)$. Kesimpulan: Body image berhubungan dengan satus gizi, dimana semakin meningkat status gizi maka akan diukuti penurunan body image. Walaupan perilaku makan remaja sehat tetapi masih mengalami gangguan status gizi yaitu overweight dan obesitas sehingga perlu dilakukan penelitian lebih lanjut terkait faktor lain seperti aktifitas fisik yang dapat mempengaruhi status gizi remaja.
\end{abstract}

\section{Abstract}

Background: Adolescents need balanced nutrition to increase physical growth and development very rapidly. In Indonesia, the nutritional problems in adolescents are complex, namely obesity, malnutrition, and micronutrient deficiencies such as anemia. Adolescent nutritional status is influenced by various factors such as eating behavior and body image. Objective: This study aims to identify the relationship between eating behavior, body image, and nutritional status of adolescents. Method: The research design used cross-sectional. Respondents were 62 teenagers at SMAK Karitas 3 Surabaya who met the inclusion criteria and was taken using a simple random sampling technique. Eating behavior was assessed using the Eating Behavior Patterns Questionnaire. Body image is assessed by questionnaire and adolescent nutritional status is based on body mass index. Results: The study showed that $56.5 \%$ of adolescents had a positive body image, 93.5\% of adolescents with healthy eating behavior and $35.5 \%$ of nutritional status based on body mass index were in the normal category. Spearman correlation test showed that there was a significant relationship between body image and adolescent nutritional status, with a negative correlation ( $p=$ $0.0001, r=-0.447)$. There was no relationship between eating behavior and nutritional status of adolescents $(p=0.711)$. Conclusion : Body image is related to nutritional status, where the increase in nutritional status will be followed by a decrease in body image. Although the eating behavior of adolescents is healthy, they still experience nutritional status disorders, namely overweight and obesity, so further research needs to be done regarding other factors such as a physical activity that can affect the nutritional status of adolescents. 


\section{PENDAHULUAN}

Remaja sangat memerlukan zat gizi yang seimbang untuk peningkatan pertumbuhan fisik dan perkembangan yang sangat pesat (Almatsier, Soetardjo, \& Soekatri, 2011). Agar kebutuhan gizi itu bisa terpenuhi maka perilaku makan remaja harus baik dan teratur (Proverawati \& Wati, 2011). Pemenuhan gizi seimbang untuk remaja adalah makanan yang dikonsumsi remaja harus banyak mengandung zat gizi sebagai sumber tenaga, pengatur dan pembangun dalam pertumbuhan dan perkembangan. Banyak faktor yang mempengaruhi kebutuhan dan pemenuhan gizi untuk aktifitas fisik, lingkungan dan penyakit stres. (Pritasari, Damayanti, \& Lestari, 2017).

Di Indonesia sendiri permasalahan gizi pada remaja cukup kompleks yaitu obesitas, gizi kurang serta kekurangan zat gizi mikro seperti anemia. Berdasarkan hasil Riset Kesehatan menunjukkan di Indonesia bahwa $25,7 \%$ remaja usia $13-15$ tahun dan $26,9 \%$ remaja usia 16-18 tahun dengan status gizi kurang tingkat ringan sampai tingkat berat (Badan Penelitian dan Pengembangan Kementerian Kesehatan RI, 2018).Selain itu terdapat $8,7 \%$ remaja usia $13-15$ tahun dan $8,1 \%$ remaja usia 16-18 tahun dengan kondisi kurus dan sangat kurus. Sedangkan prevalensi berat badan lebih dan obesitas sebesar 16,0\% pada remaja usia 13-15 tahun dan 13,5\% pada remaja usia 16-18 tahun. Overweight dan obesitas pada remaja usia 13-15 tahun di Jawa Timur masih cukup tinggi karena angka prevalensi overweight dan obesitas di Jawa Timur di atas prevalensi nasional yakni $12 \%$ (Badan Penelitian dan Pengembangan Kementerian Kesehatan RI, 2013)

Adanya industrialisasi dan globalisasi dalam bidang makanan akan menyebabkan perubahan perilaku makan masyarakat. Adanya iklan dan promosi makanan juga dapat dipercaya berperan besar dalam mempengaruhi perilaku makan pada remaja. Keseluruhan faktor ini berpengaruh besar terhadap pengambilan keputusan seseorang untuk makan atau tidak, makanan apa yang akan dipilih dan berapa banyak yang dikonsumsi (Sudargo, Freitag, \& Rosiyani, 2014). Ketika remaja makan secara tidak teratur dan makan-makanan yang sembarangan maka seseorang tersebut bisa mengalami obesitas dan bisa mengakibatkan kekurangan gizi. Namun, bila remaja tersebut mengonsumsi sesuai dengan kebutuhan maka proporsi tubuhnya selalui ideal (Sulistyoningsih, 2012).

Status gizi remaja dipengaruhi oleh berbagai faktor (Indrasari \& Sutikno, 2020). Penelitian yang dilakukan Febriani (2018) yang menyatakan bahwa terdapat hubungan antara body image dengan status gizi pada remaja. Remaja kurus yang tidak puas terhadap citra tubuh lebih berisiko mengalami perilaku makan menyimpang. Pada kelompok status gizi obesitas dan normal, remaja perempuan yang tidak puas terhadap citra tubuhnya lebih berisiko mengalami perilaku makan menyimpang (Rahayu, 2012). Khususnya bagi remaja perempuan, tekanan sosial untuk bisa memiliki bentuk fisik yang kurus dan stigma obesitas dapat menyebabkan praktik makan tidak sehat ini terus dilakukan. Bagi remaja laki-laki cenderung rentang terhadap penggunaan minuman protein tinggi atau suplemen ketika mereka mencoba untuk membangun tambahan massa otot (Mardalena, 2017).

Perilaku makan pada remaja yang lebih menyukai makanan ringan (snack), serta sengaja tidak makan karena menginginkan bentuk tubuh yang di inginkan, dan karena kesibukkan beraktivitas seseorang menjadi lupa makan lalu hanya mengkonsumsi makanan cepat saji. Masalah lain yang terjadi pada remaja dengan makan banyak asal kenyang dengan tinggi lemak dan karbohidrat tanpa memperhatikan unsur gizi didalamnya. Perilaku makan remaja tersebut dapat berdampak pada kesehatan remaja dengan timbulnya kasus gizi seperti kekurangan gizi serta kelebihan gizi (Citerawati, Susanti, \& Rahima, 2017) Perilaku makan dapat mempengaruhi asupan zat-zat gizi yang dikonsumsi pada remaja (Supariasa, 2013). Dengan perilaku makan yang seimbang dan sesuai dengan kebutuhan tubuh maka akan menimbulkan status gizi yang baik. Tetapi sayangnya banyak remaja biasanya mengonsumsi makanan yang tidak banyak mengandung gizi yang tinggi. Remaja lebih suka dengan rasa makanan yang menggugah 
selera makanan seperti yang lebih manis dan asin (Fikawati, Syafiq, \& Veratamala, 2017). Remaja saat ini kurang mengerti pentingnya zat gizi yang terkandung dalam makanan serta fungsinya untuk tubuh. Terkadang remaja saat ini mengalami kesulitan dalam memilih jenis makanan sehingga hal ini dapat menyebabkan kurangnya zat gizi tertentu (Sulistyoningsih, 2012).

Tujuan penelitian mengidentifikasi hubungan body image dan perilaku makan dengan status gizi remaja.

\section{METODE}

Penelitian ini menggunakan metode observasi (non eksperimental) dengan rancangan penelitian cross sectional. Populasi penelitian adalah siswa di SMAK Karitas 3 Surabaya yang memenuhi kriteria inklusi yaitu berusia 14-16 tahun, dalam keadaan sehat dan bersedia diteliti. Tehnik sampling yang dugunakan adalah simple random sampling sehingga diperoleh sampel sebanyak 62 remaja. Pengumpulan data dilaksanakan tanggal 2 dan 3 Mei 2021 secara online menggunakan google form.

Perilaku makan remaja dinilai menggunakan Eating Behavior Patterns Questionnaire. Schlundt et al (2003) menyatakan bahwa Eating Behavior Patterns Questionnaire merupakan kuesioner yang berguna untuk melakukan pemeriksaan klinis terkait perilaku makan, pemeriksaan intervensi gizi baik individu atau kelompok. EBPQ merupakan pernyatan dalam Bahasa Inggris yang diterjemahkan oleh Listarina pada tahun 2013 kedalam Bahasa Indonesia dan dilakukan modifikasi. Kuesioner ini pernah digunakan untuk pengukuran perilaku makan pada mahasiswa di Yogyakarta. Pada bagian ini terdapat 19 pernyataan yang gugur dan 32 pernyataan yang cocok untuk diterapkan. Penggunaan kuesioner ini ada 3 langkah yaitu pengisian kuesioner, penjumlahan skor kemudian rata-rata dan interpretasi dari skor tersebut. Kuisioner ini terdiri dari 32 item self report pada perilaku makan sehat dan tidak sehat. Pernyataan diterjemahkan ke dalam bahasa Indonesia. Setiap item dinilai dalam 5 poin skala likert mulai dari sangat tidak setuju sampai sangat setuju.
Kuesioner ini memiliki 6 komponen yaitu makanan rendah lemak yang terdiri dari 11 pernyataan, snacking and convenience yang terdiri dari 10 pernyataan, faktor emosi yang terdiri dari 8 pernyataan, perencanaan makan yang terdiri dari 6 pernyataan, meal skipping yang terdiri dari 7 pernyataan, budaya/gaya hidup yang terdiri dari 9 pernyataan. Hasil uji coba 32 item kuesioner valid dan nilai koefisien reliabilitas yang mencukupi dengan nilai $\alpha=$ 0,692\% (Listarina, 2013).

Variabel body image dinilai menggunakan kuesioner yang disusun dengan menggunakan skala Likert dan diberi bobot nilai 1-5 untuk masing-masing item pernyataan yang terdiri dari sangat tidak setuju, tidak setuju, ragu-ragu, setuju, sangat setuju. Kuesioner body image terdiri dari 11 item pertanyaan. Total nilai bobot selanjutnya dibagi dengan total nilai bobot item pernyataan lalu dikalikan $100 \%$ untuk menghitung nilai skor. Nilai skor $0-100 \%$. Selanjutnya nilai skor dikategorikan menjadi dua kategori berdasarkan penelitian Daryono (2003) positif dengan skor nilai $\geq 61 \%$ dan negatif dengan skor nilai $<61 \%$. Kuesioner body image sudah dilakukan uji validitas dan reliabilitas yang menunjukkan nilai valid dan reliabel, dengan nilai $r$ hasil berada diantara 0.361-0.766 dan nila alpha Cronbach 0. 884 (Daryono, 2003)

Status gizi dinilai dengan indikator Indeks Masa Tubuh ( IMT) yang dikategorikan IMT < 18,5 disebut dengan underweight, IMT 18,5 - 24,9 disebut dengan normal, IMT 25 29,9 disebut overweight, IMT $\geq 30$ disebut dengan obesitas

Semua proses analisis data menggunakan paket program computer. Analisis univariat dilakukan pada masingmasing variabel untuk mengetahui distribusi frekuensi dan gambaran dari setiap variabel yang diteliti yaitu perilaku makan, body image dan status gizi remaja serta data demografi

Analisisi bivariat dilakukan untuk mengidentifikasi hubungan antara perilaku makan dan body image dengan status gizi remaja. Uji statistik yang digunakan dalam penelitian ini dengan uji korelasi Spearman. Pengolahan dan analisis data menggunakan program computer Pengolahan data statistik 
dengan tingkat kemaknaan $\mathrm{p}<0,05$ dan interval kepercayaan $95 \%$.

\section{HASIL DAN PEMBAHASAN}

\section{HASIL}

Tabel 1 Karakteristik Responden

\begin{tabular}{|c|c|c|c|}
\hline Karateristik & $\begin{array}{l}\text { Frekuensi } \\
\text { (n) }\end{array}$ & $\begin{array}{c}\text { Prosentase } \\
(\%)\end{array}$ & $\begin{array}{l}\text { Mean } \pm \\
\text { SD }\end{array}$ \\
\hline $\begin{array}{l}\text { Usia Remaja } \\
\text { (tahun) }\end{array}$ & & & $\begin{array}{c}15,48 \pm \\
0,59\end{array}$ \\
\hline Berat Badan & & & $60,17 \pm$ \\
\hline (kg) & & & 16,62 \\
\hline Tinggi Badan & & & 163,72 \\
\hline $\begin{array}{l}(\mathrm{cm}) \\
\text { Jenis Kelamin }\end{array}$ & & & $\pm 8,31$ \\
\hline Perempuan & 40 & 64.5 & \\
\hline Laki-laki & 22 & 35.5 & \\
\hline $\begin{array}{l}\text { Pernah } \\
\text { tidaknya } \\
\text { mendapatkan } \\
\text { Informasi }\end{array}$ & & & \\
\hline Ya & 49 & 79 & \\
\hline Tidak & 13 & 21 & \\
\hline $\begin{array}{l}\text { Sumber } \\
\text { Informasi }\end{array}$ & & & \\
\hline Media & 40 & 81,6 & \\
\hline Cetak & & & \\
\hline $\begin{array}{l}\text { Media } \\
\text { Elektronik }\end{array}$ & 3 & 6,1 & \\
\hline $\begin{array}{l}\text { Tenaga } \\
\text { Kesehatan }\end{array}$ & 6 & 12,3 & \\
\hline
\end{tabular}

Sumber: data primer 2021

Berdasarkan karateristik responden penelitian di SMAK Karitas 3 Surabaya, didapatkan rata-rata usia responden adalah 15 tahun. Rata-rata berat badan responden $60 \mathrm{~kg}$ dan rata-rata tinggi badan $163 \mathrm{~cm}$. Berdasarkan data pernah tidaknya mendapatkan informasi tentang perilaku makan sebanyak 79\% (49) responden pernah mendapatkan informasi, dengan sumber informasi yang didapat terbanyak dari media cetak yaitu $81,6 \%$ (40) responden.

Tabel 2 Gambaran Body Image Remaja

\begin{tabular}{lcc}
\hline Indikator & Frekuensi (n) & Prosentase $(\%)$ \\
\hline Positif & 35 & 56.5 \\
Negatif & 27 & 43.5 \\
\hline Total & 62 & 100 \\
\hline
\end{tabular}

Berdasarkan hasil gambaran body image remaja menunjukkan bahwa dari 62 responden sebanyak 56,5\% (35) responden memiliki gambaran body image yang positif, sedangkan $43,5 \%$ (27) responden yang memiliki memiliki gambaran bogy image yang negatif.

Tabel 3 Perilaku Makan Remaja

\begin{tabular}{lcc}
\hline \multicolumn{1}{c}{ Indikator } & $\begin{array}{c}\text { Frekuensi } \\
(\mathrm{n})\end{array}$ & $\begin{array}{c}\text { Prosentase } \\
(\%)\end{array}$ \\
\hline $\begin{array}{l}\text { Perilaku makan sehat } \\
\text { Perilaku makan tidak }\end{array}$ & 58 & 93,5 \\
sehat & 4 & 6,5 \\
\hline Total & 62 & 100 \\
\hline Sumber: data primer 2021 & \\
\multicolumn{3}{c}{ Hasil penelitian menunjukkan bahwa } \\
dari 62 responden yang memiliki perilaku \\
makan sehat sebanyak 93,5\% (58) responden, \\
sedangkan yang memiliki perilaku makan tidak \\
sehat sebanyak 6,5\%(4) responden.
\end{tabular}

Tabel 4 Status Gizi Remaja

\begin{tabular}{lcc}
\hline \multicolumn{1}{c}{ Indikator } & Frekuensi (n) & Prosentase (\%) \\
\hline Underweight & 19 & 30,7 \\
Normal & 22 & 35,5 \\
Overweight & 15 & 24,2 \\
Obesitas & 6 & 9,6 \\
\hline Total & 62 & 100 \\
\hline Sumber: data primer 2021 \\
\multicolumn{3}{c}{ Berdasarkan tabel 5 menunjukkan } \\
bahwa dari 62 responden yang remaja dengan \\
status gizi katogori underweight sebanyak \\
$(30,7 \%) \quad 19$ responden, normal sebanyak \\
$(35,5 \%)$ 22 responden, overweight sebanyak \\
$(24,2 \%) \quad 15$ responden, obesitas kelas 1 \\
sebanyak $(9,6 \%)$ 6 responden.
\end{tabular}

Tabel 5 Hubungan Body Image dengan Status Gizi Remaja

\begin{tabular}{|c|c|c|c|c|}
\hline & $\begin{array}{c}\text { Under } \\
\text { weight } \\
(n=19)\end{array}$ & $\begin{array}{c}\text { Normal } \\
(n-22)\end{array}$ & $\begin{array}{c}\text { Overwe } \\
\text { ight } \\
(n=15)\end{array}$ & $\begin{array}{l}\text { Obesita } \\
\text { s }(n=6)\end{array}$ \\
\hline $\begin{array}{l}\text { Body } \\
\text { Image } \\
\text { Positif } \\
(n=4)\end{array}$ & $\begin{array}{c}15 \\
(42.9 \\
\%)\end{array}$ & $\begin{array}{c}12 \\
(34.2 \% \\
)\end{array}$ & $7(20 \%)$ & $\begin{array}{c}1(2,9 \% \\
)\end{array}$ \\
\hline $\begin{array}{l}\text { Negati } \\
f \\
(n=27 \\
)\end{array}$ & $\begin{array}{c}4 \\
(14.8 \%)\end{array}$ & $\begin{array}{c}10 \\
(37 \%)\end{array}$ & $\begin{array}{c}8 \\
(29.6 \% \\
)\end{array}$ & $\begin{array}{c}5(18.5 \\
\%)\end{array}$ \\
\hline \multicolumn{5}{|c|}{$\mathrm{P}=0,0001, \mathrm{r}=-0,447$} \\
\hline
\end{tabular}

Sumber: data primer 2021 
Berdasarkan tabel 2 menunjukkan dari 27 responden yang memiliki body image negatif sebanyak 10 responden $(37 \%)$ status gizinya normal, 8 responden $(29,6 \%)$ overweight, 5 responden $(18,5 \%)$ obesitas dan 4 responden $(14,8)$ dengan status gizi underweight. Dari 35 resonden yang memiliki body image positif, sebayak 15 responden $(42,9 \%)$ dengan status gizi underweight, 12 responden $(34,2 \%)$ normal, 7 responden $(20 \%)$ overweight dan 1 responden $(2,9 \%)$ obesitas kelas 1.

Hasil uji rank spearman nilai $\mathrm{p}>\alpha$ yang berarti ada hubungan antara body image dengan status gizi remaja. Correlation Coefficient ( $r$ ) menunjukkan nilai $-0,447$ dimana semakin meningkat status gizi remaja maka akan diikuti body image yang semakin turun dengan kekuatan hubungan sedang

Tabel 6 Hubungan Perilaku Makan dengan dengan Status Gizi Remaja

\begin{tabular}{lllll}
\hline & $\begin{array}{l}\text { Under } \\
\text { weight } \\
(\mathrm{n}=19)\end{array}$ & $\begin{array}{l}\text { Normal } \\
(\mathrm{n}-22)\end{array}$ & $\begin{array}{l}\text { Overweight } \\
(\mathrm{n}=15)\end{array}$ & $\begin{array}{l}\text { Obesitas } \\
(\mathrm{n}=6)\end{array}$ \\
\hline $\begin{array}{l}\text { Perilaku } \\
\text { Makan }\end{array}$ & & 1 & 2 & 0 \\
$\begin{array}{l}\text { Tidak } \\
\text { Sehat } \\
(\mathrm{n}=4)\end{array}$ & 1 & $(25 \%)$ & $(25 \%)$ & $(50 \%)$ \\
$\begin{array}{l}\text { Sehat } \\
(\mathrm{n}=58)\end{array}$ & 18 & 21 & 13 & 6 \\
\hline \multicolumn{5}{c}{$\mathrm{p}=0,711$} \\
\hline
\end{tabular}

Sumber: data primer 2021

Berdasarkan tabel 2 menunjukkan bahwa dari 62 responden terdapat 58 responden yang memiliki perilaku makan sehat terdiri dari $31 \%$ (18) responden underweight, $36,2 \%$ (21) responden normal, 22,4 (13) responden. Dari 4 responden yang memiliki perilaku makan tidak sehat ada $50 \%$ (2) responden overweight.

Hasil uji rank spearman menunjukkan bahwa nilai $\mathrm{p}>\alpha$ yang berarti tidak ada hubungan antara perilaku makan dengan status gizi remaja.

\section{PEMBAHASAN}

Hasil penelitina ini menujukkan mayoritas remaja memiliki gambaran body image yang positif. Hasil ini sejalan dengan penelitian yang dilakukan sebelumnya bahwa sebagian besar remaja memiliki gambaran citra tubuh yang positif (Yusintha, 2018). Body image terbentuk karena adanya tingkah laku pikiran, keyakinan dan kepercayaan individu tentang keadaan fisiknya (Nur \& Ayu, 2012). Masa remaja merupakan tahap penting dalam pengembangan body image (Press, 2015). Banyak hal yang mempengaruhi body image termasuk media sosial, teman sebaya yang membantu membentuk keyakinan tentang tubuh ideal yang dirasakan (Press, 2015). Remaja cenderung memperhatikan penampilan dirinya agar terlihat ideal dan menarik

Berdasarkan hasil pengukuran perilaku makan melalui kuesioner Eating Behaviour Patterns Questionnaire diperoleh hasil bahwa mayoritas remaja (94\%) sudah menjalankan perilaku makan yang sehat. Responden dengan perilaku makan sehat ada sebagian besar sudah mendapatkan informasi mengenai perilaku makan. Menurut Wijaya (2020) faktor tingkat pengetahuan serta akses informasi kesehatan, dengan mendapatkan informasi tentang perilaku makan yang sehat maka perilaku makan remaja juga baik begitu juga sebaliknya karena remaja cenderung memilih makanan sesuai dengan informasi yang didapat disekitarnya. Informasi tentang perilaku makan yang sehat dapat didapatkan melalui berbagai sumber. Pada penelitian ini remaja pernah mendapatkan informasi perilaku makan melalui media cetak, media elektronik dan tenaga kesehatan.

Menurut Wulandary et al., (2020) masa remaja pertengahan dengan umur 14 - 16 tahun memiliki perilaku makan sehat karena pada masa ini remaja lebih memperhatikan pola makan dan cenderung memperhatikan bentuk tubuhnya. Penelitian Hendarini, (2018) menunjukkan ada kesesuaian dimana masa pertumbuhan dan perkembangan pada remaja pertengahan dengan usia 14-16 tahun memiliki perilaku makan yang sehat, mereka mulai memilih untuk makan di rumah sehingga bisa terkontrol untuk makan dengan baik daripada makan diluar dan pada masa pertengahan ini mulai tertarik dengan lawan jenis sehingga lebih memperhatikan penampilannya.

Pada penelitian ini menunjukkan bahwa $24,2 \%$ remaja memiliki status gizi overweight. 
Menurut Fikawati et al., (2017) asupan makan yang berlebihan, kurangnya aktivitas fisik dan sosial ekonomi keluarga berhubungan dengan status gizi pada remaja. Menurut Hatta, (2019) remaja hanya sering mementingkan enak tidaknya makanan yang dikonsumsi dan kurangnya konsumsi makanan tinggi serat seperti buah dan sayur, kebanyakan remaja sering makan-makanan cepat saji/ fast food. Makan-makanan cepat saji/ fast food dan jarang mengkonsumsi sayur dan buah dapat mengakibatkan asupan makanan yang tidak seimbang akibatnya dapat menyebabkan gizi lebih.

Menurut Nur Amalia (2016) pola makan yang salah dan juga terdapat pengaruh lingkungan sekitar seperti mudahnya akses untuk membeli makanan cepat saji. Menurut Imtihani (2013) faktor lain yang dapat mempengaruhi status gizi remaja adalah tergiurnya promosi di media cetak/elektronik. Memilih makanan cepat saji remaja beranggapan lebih praktis dan tertarik untuk mencoba ketika melihat kemasan dan penampilan makanan melalui media cetak/elektronik dapat memberikan kontribusi asupan makanan tinggi lemak dan rendah zat gizi.

Hasil penelitian ini menunjukkan ada hubungan antara body image dengan status gizi remaja. Correlation Coefficient ( $\rho)$ menunjukkan nilai $-0,447$ dimana semakin meningkat status gizi remaja maka akan diikuti body image yang semakin turun dengan kekuatan hubungan sedang. Hasil penelitian ini sejalan dengan penelitian yang dilakukan sebelumnya bahwa terdapat hubungan yang signifikan antara citra tubuh dengan status gizi (Bimantara, Adriani, \& Suminar, 2019). Yusintha (2018) juga menyatakan semakin tinggi ketidakpuasan terhadap citra tubuh, maka status gizinya semakin tidak normal. Pada usia remaja khususnya remaja putri mulai memperhatikan penampilan fisiknya. Penelitian lain juga menyebutkan bahwa prevalensi ketidakpuasan body image lebih tinggi di antara remaja yang mengalami kelebihan berat badan atau obesitas (Santana et al., 2013). Remaja khususnya perempuan cenderung menginginkan tubuh yang kurus atau ramping daripada gemuk (Zaccagni,
Masotti, Donati, Mazzoni, \& Gualdi-russo, 2014). Pada usia remaja khususnya remaja putri mulai memperhatikan penampilan fisiknya. remaja khususnya putri seringkali tidak puas dengan bentuk tubuhnya sehingga melakukan berbagia usaha untuk menurunkan berat badannya sesuai dengan yang diinginkan. Meskipun remaja putri mempunyai bentuk tubuh yang ideal tetapi remaja cenderung menilai ukuran tubuhnya lebih besar dari ukuran sebenarnya. Hal ini menyebabkan remaja terkadang melakukan upaya penurunan berat badan dengan cara yang tidak sehat (Nomate, Nur, \& Toy, 2017)

Berdasarkan hasil penelitian bahwa tidak ada hubungan antara perilaku makan dengan status gizi remaja. Hasil ini sejalan dengan penelitian yang dilakukan oleh Purnama, (2020) yang menyebutkan bahwa tidak ada hubungan perilaku makan dengan status gizi remaja. Namun tidak sejalan dengan penelitian. Namun berbeda dengan temuan Widianti \& Candra, (2012) bahwa terdapat hubungan yang bermakna antara perilaku makan dengan status gizi remaja putri. Pada penelitian ini menunjukkan walaupun perilaku makannya sehat tetapi masih mengalami gangguan status gizi yaitu overweight dan obesitas. Pada tempat penelitian meskipun perilaku makan remaja sehat, dimasa pandemi saat ini remaja mengeluh kurangnya aktivitas karena kegiatan sekolah lebih banyak dilakukan secara daring. Tingkat aktivitas fisik pada remaja yang cenderung rendah dapat meningkatkan resiko kelebihan berat badan bahkan sampai obesitas.

Perilaku makan yang sehat belum tentu menyebabkan status gizi yang tidak normal begitu juga dengan sebaliknya. Perilaku makan bukan satu-satunya yang mempengaruhi status gizi remaja. Konsumsi energi dan aktifitas fisik juga merupakan faktor yang berkontribusi terhadap status gizi remaja

\section{KESIMPULAN}

Berdasarkan hasil penelitian dapat disimulkan bahwa body image signifikan berhubungan negative dengan status gizi remaja, dimana semakin meningkat status gizi akan diikuti penurunan body image begitu juga sebaliknya. Tidak ada hubungan yang 
signifikan antara perilaku makan dengan status gizi remaja. Perilaku makan yang sehat tidak selalu diikuti dengan status gizi baik pada remaja.

Pihak sekolah melalui UKS sekolah diharapka dengan memberikan atau memfasilitasi para siswa dengan memberikan pendidikan kesehatan atau informasi mengenai pentingnya perilaku makan yang sehat untuk mencapai status gizi yang baik. Penelitian lanjutan perlu dilakukan untuk melihat korelasi status gizi dari faktor lain seperti aktifitas fisik

\section{DAFTAR PUSTAKA}

Almatsier, S., Soetardjo, S., \& Soekatri, M. (2011). Gizi Seimbang dalam Daur Kehidupan. Jakarta: PT Gramedia Pustaka Utama.

Badan Penelitian dan Pengembangan Kementerian Kesehatan RI. (2013). Riset Kesehatan Dasar (Riskesdas 2013). Jakarta: Kementerian Kesehatan RI.

Badan Penelitian dan Pengembangan Kementerian Kesehatan RI. (2018). Laporan Nasional Riskesdas 2018. Jakarta: Kementerian Kesehatan RI. https://doi.org/10.1017/CBO9781107415 324.004

Bimantara, M. D., Adriani, M., \& Suminar, D. R. (2019). Hubungan Citra Tubuh dengan Status Gizi pada Siswi di SMA Negeri 9 Surabaya The Relationship between Body Image and Nutritional Status of Female Students in Senior High School 9 Surabaya. Amerta Nutr, 85-88. https://doi.org/10.2473/amnt.v3i2.2019.8 5-88

Citerawati, Y. W., Susanti, N., \& Rahima, D. (2017). Proses Asuhan Gizi Terstandar Komunitas. Yogyakarta: Trans Medika.

Febriani, R. T. (2018). Analisis Faktor Yang Mempengaruhi Status Gizi Lebih Remaja Di Kota Malang. Universitas Jember.

Fikawati, S., Syafiq, A., \& Veratamala, A. (2017). Gizi Anak dan Remaja. Depok: PT Raja Grafindo Persada.

Hatta, H. (2019). Hubungan Konsumsi Fast Food Dengan Status Gizi Siswa Di SMP Negeri 1 Limboto Barat. Jurnal Kesehatan Masyarakat, 4(2), 41-46. https://doi.org/10.31943/afiasi.v4i2.60
Hendarini, A. T. (2018). Pengaruh Body Image dan Kebiasaan Makan dengan Status Gizi di SMAN 1 Kampar Tahun 2017. Jurnal Gizi, 2(2), 138-145.

Imtihani, T. R., \& Noer, E. R. (2013). Hubungan Pengetahuan, Uang Saku, Dan Peer Group Dengan Frekuensi Konsumsi Makanan Cepat Saji Pada Remaja Putri. Journal of Nutrition College, 2(1), 162169. https://doi.org/10.14710/jnc.v2i1.2112

Indrasari, O. R., \& Sutikno, E. (2020). Faktor Yang Mempengaruhi Status Gizi Remaja Usia 16-18 Tahun. Jurnal Kesehatan Indonesia (The Indonesian Journal of Health), X(3), 128-132.

Listarina, M. (2013). Hubungan Antara Pola Makan Dan Perilaku Makan Dengan Status Gizi Mahasiswa S1 Fakultas Non Kesehatan Universitas Gadjah Mada. Gadjah Mada Yogyakarta.

Mardalena, I. (2017). Dasar-DasarIlmu Gizi Dalam Keperawatan. Yogyakarta: Pustaka Baru Press.

Nomate, E. S., Nur, M. L., \& Toy, S. M. (2017). Hubungan Teman Sebaya, Citra Tubuh Dan Pola Konsumsi Dengan Status Gizi Remaja Putri. Unnes Journal of Public Health, 6(3).

Nur Amalia, R., Sulastri, D., \& Semiarty, R. (2016). Hubungan Konsumsi Junk Food dengan Status Gizi Lebih pada Siswa SD Pertiwi 2 Padang. Jurnal Kesehatan Andalas, 5(1), 185-190. https://doi.org/10.25077/jka.v5i1.466

Press, D. (2015). Weight status and body image perceptions in adolescents: current perspectives, 149-158.

Pritasari, Damayanti, D., \& Lestari, N. T. (2017). Gizi Dalam Daur Kehidupan. Jakarta: Kementerian Kesehatan Republik Indonesia.

Proverawati, A., \& Wati, E. K. (2011). Ilmu Gizi Untuk Keperawatan dan Gizi Kesehatan. Yogyakarta: Nuha Medika.

Purnama, N. L. A. (2020). Perilaku makan dan status gizi remaja. Jurnal Penelitian Kesehatan, 7(2), 57-62. Retrieved from http://www.jurnal.stikvinc.ac.id/index.ph p/jpk/article/view/172

Rahayu, A. (2012). Hubungan Antara Citra 
Tubuh Dengan Perilaku Makan. Universitas Gadjah Mada.

Santana, L. P., R, R. D. C., Ana, M. O., Rosa, M., Ester, P. C., Pinto, D. J., ... Salvador, E. N. (2013). Factors associated with body image dissatisfaction among adolescents in public schools students in Salvador , Brazil. https://doi.org/10.3305/nh.2013.28.3.628 1

Sudargo, T., Freitag, H., \& Rosiyani, F. (2014). Pola Makan dan Obesitas. Yogyakarta: Gadjah Mada University Press.

Sulistyoningsih, H. (2012). Gizi untuk Kesehatan Ibu dan Anak. Yogyakarta: Graha Ilmu.

Supariasa, I. D. N. (2013). Pendidikan dan Konsultasi Gizi. Jakarta: EGC.

Widianti, N., \& Candra, A. K. (2012). Hubungan Antara Body Image dan Perilaku Makan Dengan Status Gizi Remaja Putri Di SMA Theresiana Semarang. Journal of Nutrition College, 1(1), 398-404.

Wijaya, U. L., Widjanarko, B., \& Indraswari, R. (2020). Faktor-Faktor Yang Berhubungan Dengan Perilaku Makan Berisiko Gizi Lebih Pada Remaja Sma Di Kota Semarang. Jurnal Kesehatan Masyarakat, 8(3), 426-431.

Wulandary, H., Tasnim, \& Sulfianti. (2020). Gizi dan Kesehatan. Jakarta: Yayasan Kita Menulis.

Yusintha, A. N. (2018). Hubungan Antara Perilaku Makan dan Citra Tubuh dengan Status Gizi Remaja Putri Usia 15-18 Tahun Relationship between Eating Behavior and Body Image with Nutritional Status of Adolescent Girl Age 15-18 Years, 147-154. https://doi.org/10.20473/amnt.v2.i2.2018. 147-154

Zaccagni, L., Masotti, S., Donati, R., Mazzoni, G., \& Gualdi-russo, E. (2014). Body image and weight perceptions in relation to actual measurements by means of a new index and level of physical activity in Italian university students, 1-8. 